\title{
Steinert's disease
}

\author{
Taro Shimizu, ${ }^{1}$ Hideo Nozaki, ${ }^{2}$ Yasuharu Tokuda ${ }^{3}$
}

${ }^{1}$ University of Hawaii, Hawaii, USA

${ }^{2}$ National Center for Child Health and Development, Tokyo, Japan

${ }^{3}$ University of Tsukuba, Ibaraki, Japan

\section{Correspondence to}

Dr Taro Shimizu,

shimizutaro7@gmail.com

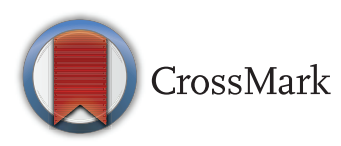

To cite: Shimizu T Nozaki H, Tokuda Y. BMJ Case Rep Published online: [please include Day Month Year] doi:10.1136/bcr-2013201846

\section{DESCRIPTION}

On a cold winter's day, a 52-year-old man presented with a 3-year history of fatigue and gait disturbance. He had previously been diagnosed with Steinert's disease (type 1 myotonic dystrophy) through genetic testing showing cytosine-thymineguanine repeats in the dystrophia myotonicaprotein kinase gene. He sometimes found it difficult to sit up in bed because of weakness of his neck muscles. On examination, marked atrophy of the temporal, masseter and sternocleidomastoid muscles with frontal alopecia was observed (figure 1). Muscle strength was intact but was grade $4 / 5$ in the hip extensors and flexors. Grip myotonia

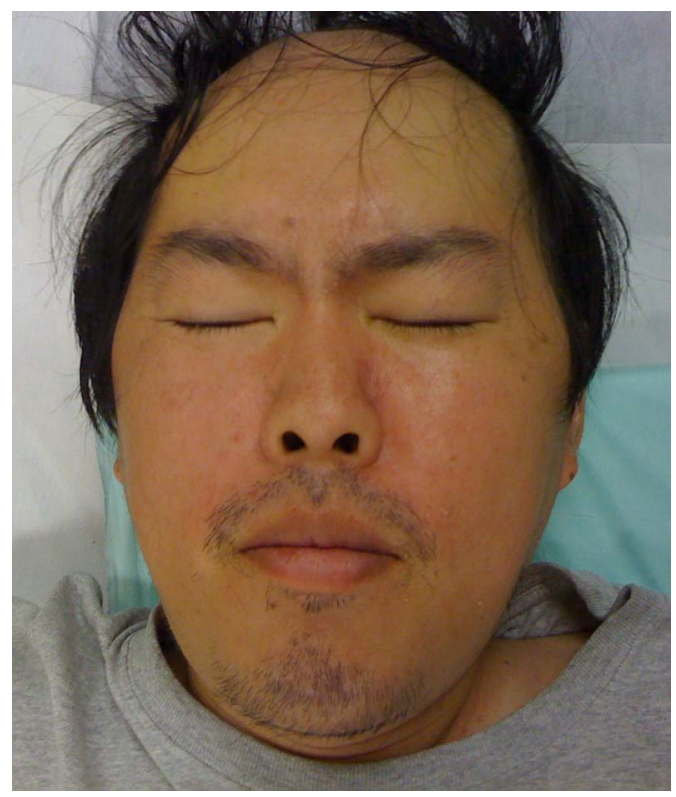

Figure 1 A marked atrophy of the temporal, masseter and sternocleidomastoid muscles with frontal alopecia.

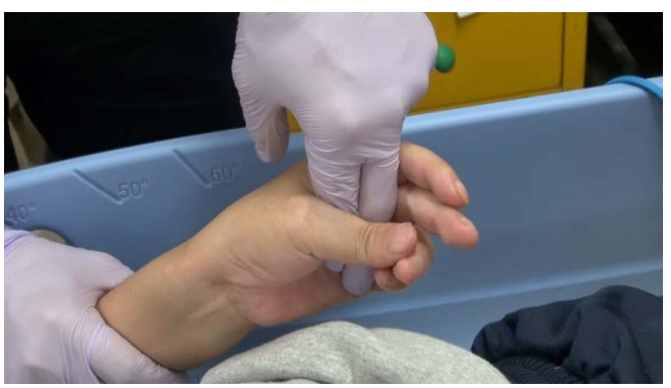

Video 1 Grip myotonia.

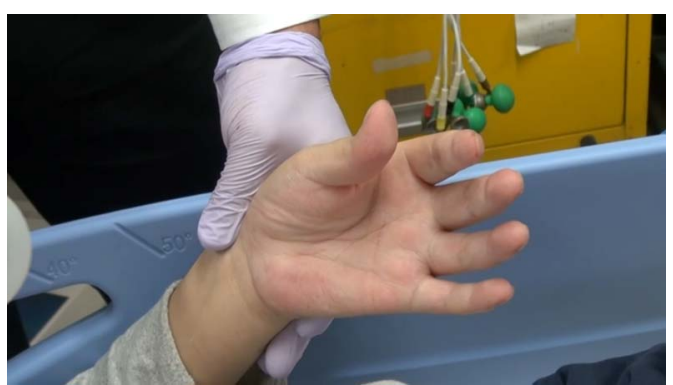

Video 2 Percussion myotonia.

and percussion myotonia were observed (videos 1 and 2). In Steinert's disease, myotonia is observed most consistently in small muscles including the hand intrinsic muscles, typically elicited as grip myotonia and percussion myotonia. ${ }^{1}$ Muscular symptoms are seen especially in the early stages of the disease, typically aggravated by cold and stress. ${ }^{2}$ The day the patient visited was a cold winter's day, which may have aggravated his symptoms.

\section{Learning points}

- Steinert's disease (myotonic dystrophy type 1) is a multisystem disorder mainly characterised by skeletal muscle weakness and myotonia.

- Myotonia is prominent especially in the early stages of the illness, which is aggravated by cold and stress. It is seen most consistently in the facial and hand intrinsic muscles.

Acknowledgements The authors would like to express their gratitude to Dr Hideo Nozaki for reviewing and editing our videos.

Contributors TS and YT participated in patient care. TS wrote the manuscript, and YT revised it.

\section{Competing interests None.}

Patient consent Obtained.

Provenance and peer review Not commissioned; externally peer reviewed.

\section{REFERENCES}

1 Avaria M, Patterson V. Myotonic dystrophy: relative sensitivity of symptoms signs and abnormal investigations. Ulster Med J 1994:63:151.

2 Machuca-Tzili L, Brook D, Hilton-Jones D. Clinical and molecular aspects of the myotonic dystrophies: a review. Muscle Nerve 2005;32:1. 
Copyright 2013 BMJ Publishing Group. All rights reserved. For permission to reuse any of this content visit http://group.bmj.com/group/rights-licensing/permissions.

BMJ Case Report Fellows may re-use this article for personal use and teaching without any further permission.

Become a Fellow of BMJ Case Reports today and you can:

- Submit as many cases as you like

- Enjoy fast sympathetic peer review and rapid publication of accepted articles

- Access all the published articles

- Re-use any of the published material for personal use and teaching without further permission

For information on Institutional Fellowships contact consortiasales@bmjgroup.com

Visit casereports.bmj.com for more articles like this and to become a Fellow 